\title{
THE LAW'S AUTONOMY AND A PRACTICAL LAW-VIEW. Preliminaries to Legal Discourse ANALYSIS
}

\author{
MACIEJ PICHLAK*
}

\section{INTRODUCTION}

The main objective of this study is to propose some preliminary points for a new methodological approach to one of the classic problems of legal thought: the problem of the autonomy of law. To that end, it exposes some shortcomings of previous studies, as well as the main challenges that theoretical efforts in that field should attempt to overcome.

The law's autonomy is herein understood first and foremost as a practical idea - a part of a practical understanding of law (law-view). Thus, the proposed research perspective should scrutinize the interpretations which are shared by social agents; such an approach is consistent with Descriptivism as an instance of an analytical tradition, whereas in social science it may be represented by Grounded Theory ${ }^{1}$. Analytical tradition and social science are not mentioned here by accident, as the paper recommends Sociological Discourse Analysis (SDA) as a plausible perspective for potential research. The main advantage of SDA in regard to the analysed problem is the conjunction of analytical methods of linguistic studies with empirical research typical of social science.

Within the proposed methodology of SDA, the paper elucidates the main points of understanding of the relation between legal practice (together with particular linguistic activities belonging to it) and its structural framework of the implicitly accepted law-view, a part of which is the idea of the law's autonomy. These relations are defined in line with the theory of reflexivity of social life, which is crucial for the dialectical nature of the analysed relationship.

DOI: 10.1515/wrlae-2015-0006

* Assistant Professor in Department of Legal Theory and Philosophy of Law, University of Wrocław; mpichlak@prawo.uni.wroc.pl.

${ }^{1}$ Barney G Glaser and Anselm L Strauss, The Discovery of Grounded Theory: Strategies for Qualitative Research (Aldine 1967); for a similar view in legal science see Baudouin Dupret, Prawo w naukach spolecznych (Joanna Stryjczyk tr. Disciplinae vol 5, Oficyna Naukowa 2010). 


\section{THE CONCEPT OF AUTONOMY IN LEgAL SCIENCE}

In the most general terms, it should be observed that the very question of the autonomy of law belongs to the foundations of our own way of understanding the law and its significance for society. The idea of autonomy is generally accepted as a crucial aspect of European legal culture; it is also usually paired with the positivist account of law, which remains dominant ${ }^{2}$.

The autonomy of law is also a well-known and broadly discussed issue in the existing subject literature. It is interpreted differently within such traditions as legal positivism, natural law, legal realism, communicative theories of law, critical and postmodern theories. It may be said that each theory of law which attempts to be a sufficiently general one must wrestle with the question of autonomy. The state of existing discourse, with the exception of critical approaches, has been captured by Włodzimierz Gromski ${ }^{3}$.

The most plausible starting point for a study on the law's autonomy is its legal-positivistic interpretation. Within that tradition, the concept of autonomy plays a pivotal role; it closely corresponds with two presumptions determining the identity of the contemporary positivistic approach: the separability thesis and the social thesis ${ }^{4}$. Setting aside the writings of 'The Classics' of legal positivism, the most influential interpretation of the concept has been offered by Joseph Raz ${ }^{5}$. Other significant explanations can be found in the writings of such scholars as Jules Coleman ${ }^{6}$, Scott Shapiro ${ }^{7}$, Gerald Postema ${ }^{8}$, Kenneth Himma ${ }^{9}$, Tom Campbel1 ${ }^{10}$, Jeremy Waldron ${ }^{11}$,

\footnotetext{
${ }^{2}$ See Joseph Raz, Ethics in the Public Domain: Essays in the Morality of Law and Politics (Clarendon Press 1994); Robert P George (ed), The Autonomy of Law: Essays on Legal Positivism (Oxford University Press 1996); Jürgen Habermas, Between Facts and Norms: Contributions to a Discourse Theory of Law and Democracy (William Rehg tr, Polity Press 1996); Włodzimierz Gromski, Autonomia i instrumentalny charakter prawa (Kolonia Ltd 2000); Kaarlo Tuori, Critical Legal Positivism (Applied legal philosophy, Ashgate 2002); from historical viewpoint see Harold J Berman, Law and Revolution: The Formation of the Western Legal Tradition (Harvard University Press 1983).

${ }^{3}$ Gromski (n 2).

${ }^{4}$ Kenneth E Himma, 'Inclusive Legal Positivism' in Jules L Coleman and Scott Shapiro (eds), The Oxford Handbook of Jurisprudence and Philosophy of Law (Oxford University Press 2004); Manuel Atienza, 'Is Legal Positivism a Sustainable Legal Theory?' in Jerzy Stelmach and Tomasz Gizbert-Studnicki (eds), Law and Legal Cultures in the 21st Century: 23rd IVR World Congress, August 1-6, 2007, Cracow, Poland; Plenary Lectures: Diversity and Unity (Wolters Kluwer Polska 2007).

${ }^{5}$ Raz (n 3); Joseph Raz, 'Postema on Law's Autonomy and Public Practical Reasons: Critical Comment' [1998] Legal Theory.

${ }^{6}$ Jules L Coleman, The Practice of Principle: In Defence of a Pragmatist Approach to Legal Theory (Oxford University Press 2001).

${ }^{7}$ Scott Shapiro, 'The Difference That Rules Make' in Brian Bix (ed), Analyzing Law: New Essays in Legal Theory (Clarendon Press 1998).

${ }^{8}$ Postema Gerald J, 'Law's Autonomy and Public Practical Reason' in Robert P George (ed), The Autonomy of Law: Essays on Legal Positivism (Oxford University Press 1996).

${ }^{9}$ Kenneth E Himma, 'Law's Claim of Legitimate Authority' in Jules L Coleman (ed), Hart's Postscript: Essays on the Postscript to The concept of Law (Oxford University Press 2001).

10 Tom Campbell, The Legal Theory of Ethical Positivism (Applied legal philosophy, Dartmouth 1996).

11 Jeremy Waldron, 'Normative (or Ethical) Positivism' in Jules L Coleman (ed), Hart's Postscript: Essays on the Postscript to The concept of Law (Oxford University Press 2001).
} 
and (from a critical perspective) David Dyzenhaus ${ }^{12}$. More examples can be explored in the volume The Autonomy of Law. Essays on Legal Positivism ${ }^{13}$; comparisons of selected positivistic interpretations of the concept of autonomy have been carried out by Maciej Pichlak ${ }^{14}$.

The concept of autonomy of law has also been discussed within Polish legal science, which has engaged the issue from an analytical perspective ${ }^{15}$. The concept has been also put under scrutiny in respect of its correlations with legal language (in Polish legal scholarship, see particularly the contributions of Marcin Matczak and Artur Kozak) ${ }^{16}$. The aforementioned authors argue for the necessity of a professional, autonomous language for construing the autonomy of law.

\section{Challenging the LAW'S AUtonomy}

These broad and exhaustive jurisprudential discussions notwithstanding, the need for a new theoretical approach to the old problem of autonomy has emerged. There are at least three critical reasons for this novel inquiry.

The first reason relates to institutional transformations in modern societies, still not plausibly explained within studies of the autonomy of law. These changes may be described very briefly as the increasing reflexivity of social institutions, the law included. Institutional reflexivity, interpreted in accordance with the perspective of Anthony Giddens, "consists in the fact that social practices are constantly examined and reformed in the light of incoming information about those very practices, thus constitutively altering

\footnotetext{
12 David Dyzenhaus, 'Positivism's Stagnant Research Programme' (2000) 20(4) Oxford Journal of Legal Studies.

${ }^{13}$ George (ed) (n 2).

${ }^{14}$ Maciej Pichlak, 'Autonomia argumentacji prawniczej: między refleksją etyczną a analitycznym prawoznawstwem' in Przemysław Kaczmarek (ed), Lokalny $i$ uniwersalny charakter interpretacji prawniczej (Z Zagadnień Teorii i Filozofii Prawa. Wydawnictwo Uniwersytetu Wrocławskiego 2009); Maciej Pichlak, 'Teza o autonomii prawa we współczesnym myśleniu prawniczym’ in Michał Araszkiewicz (ed), Z punktu widzenia filozofii prawa (Zeszyty Prawnicze TBSP UJ. Uniwersytet Jagielloński 2009); Maciej Pichlak, 'Obrona zamkniętego systemu źródeł prawa we współczesnym pozytywizmie prawniczym' in Wiesław Staśkiewicz and Tomasz Stawecki (eds), Dyskrecjonalność w prawie (LexisNexis 2010); Maciej Pichlak, 'The Autonomy of Law as a Moral Claim: on Some Paradox of Legal Positivism' in Bartosz Wojciechowski, Piotr W Juchacz and Karolina M Cern (eds), Legal Rules, Moral Norms and Democratic Principles (DIALOGOS vol 15. Peter Lang Edition 2013).

15 See esp. Wiesław Lang, Prawo $i$ moralność (PWN 1989); Gromski, Autonomia $i$ instrumentalny charakter prawa (n 2); as well as essays collected in Włodzimierz Gromski (ed), Autonomia prawa (Z Zagadnień Teorii i Filozofii Prawa, Kolonia Ltd 2001); Joanna Helios (ed), Autonomia prawa ze stanowiska teorii i filozofii prawa (Z Zagadnień Teorii i Filozofii Prawa, Kolonia Ltd 2003).

${ }^{16}$ Marcin Matczak, Summa iniuria: O błędzie formalizmu w stosowaniu prawa (Scholar 2007); Artur Kozak, Myślenie analityczne w nauce prawa i praktyce prawniczej (Maciej Pichlak ed, Wydawnictwo Uniwersytetu Wrocławskiego 2010).
} 
their character"17. In other words, reflexivity relies on an institution's constant readiness for a revision of its theoretical and practical foundations, due to "the principle of methodological doubt" 18 .

Processes of increasing reflexivity may be observed nowadays in the range of various legal institutions and phenomena, such as judicial review by constitutional courts, the growing role of ADR procedures, the increasing mutual penetration of private and public law, institutions of civil disobedience, structural shifts within the legal profession, the multi-central nature of modern legal orders, autonomization of law in relation to the nation-state, and still others ${ }^{19}$. At the same time, reflexivity seems prima facie to contradict the concept of autonomy; by doing this, it threatens the foundations of our legal culture and the image of law typical of this culture. Therefore, questions arise as to the real impact of reflexivity on the issue of autonomy under examination: does reflexivity affect the day-to-day practice of legal discourse, and can we plausibly note the emergence of a new form of 'reflexive autonomy'? There is a dearth of analyses exploring the mutual bonds between these two categories.

The second rationale for establishing a novel approach to the law's autonomy corresponds with the continually expanding scope and significance of discussions which - whether directly or indirectly - refer to this topic. These include such broadly discussed issues as politicization of the law, its economization, the role of ethical reflection within legal reasoning, the limits of judicial power and discretion, as well as more finegrained problems, such as the institutional structure of the judiciary, methods of legal interpretation, the participation of interest groups and lobbies in lawmaking procedures, the role of legal instruments in EU integration, etc. All these various spheres of political and scientific debate are linked by their recourse to the idea of the autonomy of law - sometimes advanced with conviction, sometimes openly criticized, and in some cases merely tacitly taken for granted.

Finally, the third reason for engaging in such research consists in some methodological deficiencies of previous studies in that field. The dominant perspective within these studies has long been the analytical approach (which, of course, does not imply the absence of other perspectives, to mention just the sociological one). Nevertheless, the concept of autonomy may be interpreted in two manners from within the analytical perspective: whether as a theoretical category, being a purely formal concept which serves the interpretation of a practice at the theoretical level (using one of the methods characteristic of analytical philosophy: paraphrase, explication, et al.), or as a practical category, reflecting an actual element of an explored practice ${ }^{20}$. This corresponds with two varieties of analytical theory: Reconstructivism (e.g. logical analysis) and Descriptivism

\footnotetext{
${ }^{17}$ Anthony Giddens, The Consequences of Modernity (Polity Press 1990) 38.

18 See also Anthony Giddens, Modernity and Self-identity: Self and Society in the Late Modern Age (Stanford University Press 1991); Ulrich Beck, Anthony Giddens and Scott Lash, Reflexive Modernization: Politics, Tradition and Aesthetics in the Modern Social Order (Stanford University Press 1994).

${ }^{19}$ See Paweł Jabłoński and Maciej Pichlak, 'Miejsce refleksji krytycznej w instytucjonalnej wiedzy o prawie' (2013) LVII-LVIII Principia 269.

${ }^{20}$ Cf. Stephen Perry, 'Interpretation and Methodology in Legal Theory' in Andrei Marmor (ed), Law and Interpretation: Essays in Legal Philosophy (Clarendon Press 1995).
} 
(linguistic analysis) $^{21}$. Naturally, these should be regarded as ideal types, since in scientific practice particular theoretical standpoints may be located somewhere between the two. Nevertheless, in the majority of cases the dominant perspective may be clearly observed.

Both varieties of analytical theory are present in studies on the autonomy of law, yet both suffer from serious, while different, weaknesses. Reconstructivism - which is represented by the majority of Polish analytical legal theory - is exposed to the threat of the fallacy of apriorism (where aspects of reality which do not 'fit' the theoretical model are excluded from the scope of analysis), as well as the fallacy of hypostatization (reifying categories which, initially meant to be purely formal, are treated from that point as direct descriptions of reality). Nevertheless, the existing research retains the weak points of Descriptivism - the dominant perspective of modern Anglo-Saxon analytical jurisprudence. Starting from the wellknown statement of Herbert Hart that his The Concept of Law may be plausibly read as a study in the field of descriptive sociology ${ }^{22}$, subsequent theoretical projects within that tradition have attempted to provide an adequate description of linguistic practice, although they have never given up trying to distinguish substantial or crucial moments of that practice from accidental ones ${ }^{23}$. Alas, their common weakness is the intuitiveness of such a description: the aspiration to adequacy has usually been based on the rather subjective perception of a particular scholar. Taking into account the fact that each analytical theory presupposes some claims from the field of social theory and/or philosophy in their accounts ${ }^{24}$, such a reliance on intuition is all the more striking.

Hence, a new approach is required, one which would overcome the limitations of descriptive analytical theory. In choosing the same descriptive orientation, the research perspective should offer a methodologically rigorous description of the linguistic practices under analysis. This aim may be achieved if, and only if, the study includes a stage involving detailed analysis of texts belonging to the scrutinized discourse. Thus, the purpose of the research may be expressed in other words as a verification of the existing claims of analytical legal science regarding the presence of the idea of autonomy within legal discourse. Moreover, this verification should be conducted in the light of the aforementioned changes in law's intellectual and institutional surroundings.

There are some studies in the existing Polish legal-theoretical literature which provide such a detailed and methodologically rigorous empirical analysis of legal discourse; however, their implications for the issue of autonomy may be only drawn indirectly. In the newest Polish

${ }^{21}$ See Janina Kotarbińska, 'Spór o granice stosowania metod logicznych' in Jerzy Pelc (ed), Semiotyka polska 1894 - 1969 (PWN 1971); Zygmunt Ziembiński, 'Deskrypcjonistyczna i rekonstrukcjonistyczna analiza języka w prawoznawstwie' [1985] Studia Prawnicze; Kozak (n 17).

${ }^{22}$ Herbert L Hart, The Concept of Law (Oxford University Press 1961).

${ }^{23}$ Brian Bix, Jurisprudence: Theory and Context (5th edn, Carolina Academic Press 2009).

${ }^{24}$ See Perry (n 20); Kozak (n 16). 
literature one may also find other pieces of research that provide a similarly rigorous empirical analysis of discourse ${ }^{25}$. Nonetheless, there is still a paucity of studies directly devoted to the autonomy of law as a practical category; in other words, studies which attempt to engage in scrutiny of the actual role of the discussed idea in discursive practices, based on a detailed analysis of these very practices.

Another element absent in previous studies is that of approaches coupling the issue of autonomy with the concept of reflexivity. This absence gives rise to the misleading impression that the notions of autonomy and reflexivity are contradictory to each other. On the other hand, premises for the possibility of their conjunction may be found in the writings of some scholars who refer indirectly to both of these notions ${ }^{26}$.

All this allows us to recommend the perspective of Sociological Discourse Analysis (SDA) as a plausible elaboration of legal studies, particularly of descriptive analytical theory. Unique to SDA is its combination of a typically analytical account of linguistic studies with methods characteristic of social science. Within this approach, discourse is understood as a system of (mutually related) linguistic utterances, carrying a social significance ${ }^{27}$. This allows for an empirical examination of linguistic practices - the element lacking in previously conducted theoretical analyses of the law's autonomy.

\section{TOWARDS A NEW METHODOLOGICAL APPROACH}

In scrutinizing the autonomy of law from the perspective of SDA, the analysed concept is regarded as a practical idea - a component of a practical understanding of law, as accepted by participants in legal practices and expressed in their contribution to legal discourse. The law's autonomy, understood as such, is to be contrasted with the idea of instrumental law, which perceives law as directly dependent on some external, extra-legal

\footnotetext{
${ }^{25}$ Matczak (n 16); Olgierd Bogucki, Wykładnia funkcjonalna w działalności najwyższych organów władzy sądowniczej (Wydział Prawa i Administracji Uniwersytetu Szczecińskiego 2011); Marek Smolak, Wykładnia celowościowa z perspektywy pragmatycznej (Wolters Kluwer Polska 2012).

${ }^{26}$ See Habermas (n 2); Marek Zirk-Sadowski, Prawo a uczestniczenie $w$ kulturze (Wydawnictwo Uniwersytetu Łódzkiego 1998); Tuori (n 2); Ewa Łętowska, 'Kilka uwag o praktyce wykładni' (2002) XI (1) Kwartalnik Prawa Prywatnego; Ewa Łętowska, 'Udział trzeciej władzy w dyskursie społecznym - sądy i trybunały najwyższych instancji' in Jerzy Hauser and Lesław Nawacki (eds), Państwo w stużbie obywateli. Księga Jubileuszowa Jerzego Światkiewicza (Biuletyn RPO: Materiały. Biuro Rzecznika Praw Obywatelskich 2005); Jerzy Leszczyński, Pozytywizacja prawa $w$ dyskursie dogmatycznym (Universitas 2010).

${ }^{27}$ Anna Duszak and Norman Fairclough, 'Wstęp: Krytyczna analiza dyskursu - nowy obszar badawczy dla lingwistyki i nauk społecznych' in Anna Duszak and Norman Fairclough (eds), Krytyczna analiza dyskursu: Interdyscyplinarne podejście do komunikacji spotecznej (Universitas 2008); Anna Horolets, 'Wprowadzenie - status dyskursu w badaniach socjologicznych' in Anna Horolets (ed), Analiza dyskursu w socjologii i dla socjologii (Wydawnictwo Adam Marszałek 2008); Ruth Wodak, 'Introduction: Discourse Studies - Important Concepts and Terms' in Ruth Wodak and Michał Krzyżanowski (eds), Qualitative Discourse Analysis in the Social Sciences (Palgrave Macmillan 2008); Piotr Pawliszak and Dorota Rancew-Sikora, 'Wprowadzenie do socjologicznej analizy dyskursu (SAD)' [2012] Studia Socjologiczne.
} 
determinants. Both of these concepts - autonomy of the law and instrumentalism of the law - should be treated as components of more comprehensive images of law. For autonomy, this broader vision should also include such concepts as the law's objectivity, formal rationality, firmness, legality, the systemic nature of law etc ${ }^{28}$.

Therefore, studies on the law's autonomy conceived from this particular perspective should answer, among others, the following questions: 1) To what extent does the idea of the autonomy of law exist within legal discourse?

2) What is the status of the idea of the law's autonomy within the law-view accepted by participants in the discourse?

3) What practical role and function does the idea have within the discourse?

These research questions assume some notions which should be further explained in order to understand them properly. These are the notions of 'law-view', 'role' and 'function'. I shall comment on them briefly. They do not serve only as conceptual tools for the planned research, but may be seen as expressions of a general theoretical and methodological perspective proposed for such a study.

It seems justified to begin with the (somewhat enigmatic) notion of 'law-view'. It stems from Ludwig Wittgenstein's concept of "world-view" (Weltbild $)^{29}$ and it refers to the most basic beliefs as to the shape and nature of the legal order ${ }^{30}$. Such beliefs, however, are mainly non-propositional, and belong to a purely practical knowledge. In other words, social agents are never able to explicitly and comprehensively express their own worldview. Indeed, this is how Wittgenstein interprets his own concept, which is reflected by another notion (closely related to the concept of Weltbild, yet much better known) of Lebensform (life form). A life form (and consequently world-view) is a practice, an "ungrounded way of acting" which "can be learned purely practically, without learning any explicit rules" ${ }^{\prime 3}$. Analogically, a law-view may be perceived as a practice of tacit accept ance of some beliefs about law. Tacit knowledge is here contrasted with its discursive kind, hence in principle it is rarely expressed explicitly, although it defines the context of discursive acts and influences the form and content of utterances by particular actors ${ }^{32}$. The last statement does not

\footnotetext{
${ }^{28}$ See Lang (n 15); Andrzej Kojder, 'Wykluczenie prawne jako fakt społeczny' in Anna Turska (ed), Prawo i wykluczenie: Studium empiryczne (Wydawnictwo C. H. Beck 2010); Maciej Pichlak, 'Różnica poglądów na tożsamość prawa w polskiej teorii' in Paweł Jabłoński (ed), Czy koniec teorii prawa? (Z Zagadnień Teorii i Filozofii Prawa. Wydawnictwo Uniwersytetu Wrocławskiego 2011).

${ }^{29}$ Ludwig Wittgenstein, On Certainty (G.E.M. Anscombe and Wright, G. H. von eds, Basil Blackwell 1969).

${ }^{30}$ The term 'worldview' serves also as an English equivalent for two other important notions in German philosophy - Weltansicht and Weltanschaung. If we include connotations of these two notions into our interpretation of the 'world-view', we will be driven to the conclusion that the latter consists not only of propositional statements about the world, but also of axiological and normative beliefs.

31 ibid. para. 94, 110.

32 See Pichlak, 'The Autonomy of Law as a Moral Claim: on Some Paradox of Legal
} 
mean, however, that agents are without any access to this kind of knowledge. In limited circumstances, due to the mechanism of reflexivity, they can make conscious use of it, as long as such use serves a clearlydefined strategic purpose.

One of the basic presumptions of contemporary humanities and social science states that this practice of Lebensform is reflected within language. The idea of mutual relations between language, action and world view is not only well known, but it has also emerged, partially independently, in many disciplines and perspectives within the realm of reflection on language, including various strands of analytical philosophy ${ }^{33}$. The prevailing contribution to defining the nature of such links has been undoubtedly made by Cognitive Linguistics ${ }^{34}$, although inspirations from Etnolinguistics came chronologically sooner (the so-called Sapir-Whorf hypothesis). Within the field of discourse studies (SDA), the theses of Cognitive Linguistics have been applied by such thinkers as Teun van Dijk in his theory of mental models as cognitive contexts of discourse ${ }^{35}$. However, while studies within classical Cognitive Linguistics have been invariably focused on the lexical and grammatical aspects of language, consistently treating a sentence as the highest unit of analysis, within the field of discourse studies a whole text becomes the superior unit of study. Hence, three primary levels of analysis can be distinguished: lexical/semantic, grammatical/syntactic, and textual.

I propose to interpret the precise relations between a sociallyconstituted world-view and a particular linguistic contribution to a discourse (text) in line with Anthony Giddens's theory of structuration ${ }^{36}$. This inspiration is reflected in the way two other concepts are understood, namely, the function and the role of a particular component of world-view in a discourse.

The notion of the function of a component of world-view (e.g. of the idea of the law's autonomy) refers to treatment of world-view as an element of a cognitive context for particular texts. In other words, texts are perceived as representations of an accepted world-view (see Social Representations Theory) ${ }^{37}$ which determines the external, a priori framework for a linguistic practice. Since this perspective on the relation between a world-view and a text strongly resembles the way social theory (in particular structuralist

\footnotetext{
Positivism' (n 14).

${ }^{33}$ See Kazimierz Ajdukiewicz, 'Obraz świata i aparatura pojęciowa' (first published 1934) in Kazimierz Ajdukiewicz, Język i poznanie (1, PWN 1985); Ludwig Wittgenstein, Philosophical Investigations (G.E.M. Anscombe, P.M.S. Hacker, and J. Schulte trs, Basil Blackwell 1953); John L Austin, 'A Plea for Excuses' (first published 1957) in John L Austin, Philosophical Papers (Clarendon Press 1961).

34 George Lakoff, 'An Essay in Cognitive Linguistics' in Han'guk Ŏnŏ Hakhoe (ed), The Linguistic Society of Korea. Linguistic in the Morning Calm: selected papers from SICOL1981 (Hanshin Publishing Co. 1982); Ronald W Langacker, Foundations of Cognitive Grammar: Vol. 1: Theoretical Prerequisites (Stanford University Press 1987); see also Jerzy Bartmiński, Językowe podstawy obrazu świata (Wydawnictwo UMCS 2007).

35 Dijk, Teun A. van, Discourse and Context: A Sociocognitive Approach (Cambridge University Press 2008).

${ }^{36}$ See Anthony Giddens, The Constitution of Society: Outline of the Theory of Structuration (Polity Press 1984); Anthony Giddens, New Rules of Sociological Method: A Positive Critique of Interpretative Sociologies (2nd edn, Polity Press 1993).

${ }^{37}$ Serge Moscovici, Social Representations (Polity Press 2000).
} 
theories) regards the relation between social structure and agency, it may be called a structural perspective. Hence, the notion of the function of the law's autonomy elucidates the impact of the idea of autonomy on a practice, in which the idea is among the elements of a law-view and defines the structural context for a legal discourse.

The objectifying approach of the structural perspective described above needs to be counterbalanced with a pragmatic perspective, in line with Giddens's remark that "neither on the level of logic, nor in our practical day-to-day lives, can we step aside the flow of action" 38 . This view affects the way in which agency is perceived. Agency which has both structural and strategic dimensions aims to achieve goals established by actors. In the case of linguistic practices this dimension finds its expression in the notion of performativity. Within this perspective, a context (world-view) constitutes not only a framework but also resources from which agents may reflexively draw for their own sake. The pragmatic perspective provides the notion of the role of the idea of autonomy, i.e. practical purposes for which the idea is deliberately and strategically used by social agents.

Furthermore, the context of a practice - which seems in the structural perspective to be objective and fixed - from the pragmatic point of view is constantly redefined and reconstructed by particular actions. A world-view is perceived here as a reflexive project, an ongoing process which not only shapes particular texts within discursive practice, but which is simultaneously shaped by these very texts. Hence, the relation between the structural and pragmatic perspectives - following the one between structural context (world-view) and agency (text) - is dialectical in nature. This conclusion, inspired by Giddens, is accepted by representatives of SDA. As Paul Gee has suggested ${ }^{39}$, it is an instance of the 'chicken and egg' dilemma: any attempt to put one of these two elements (text or world-view, pragmatic or structural approach) before the other leads inevitably to paradoxes. Rather, they remain in a mutual and reflexive relationship.

No matter how incomplete and tentative the above conclusions are, it should be clear that within the proposed methodological perspective, the introduction of the notion of reflexivity is inevitable - both for analysis of action and of context. Since reflexivity remains one of the basic practical challenges which the planned research perspective should face (see above), it may be treated as an additional advantage of the chosen perspective. On the other hand, the question which should be answered as result of the research is about the extent to which the aforementioned formal category of reflexivity is embodied in analysed discursive practices in the field of law.

\footnotetext{
${ }^{38}$ Giddens, New Rules of Sociological Method (n 36) 5.

39 James P Gee, An Introduction to Discourse Analysis: Theory and Method (Routledge 1999) 82 .
} 